\section{Peningkatan Hasil Belajar Siswa Pada Pembelajaran IPS melalui Penerapan Model Project Based Learning}

\author{
Sunardin \\ Universitas Cokroaminoto Palopo \\ Email:sunardin@uncp.ac.id \\ http://ojs.unm.ac.id/index.php/Insani/index
}

Abstrak. Penelitian ini merupakan penelitian kualitatif deskriptif yang menggunakan rancangan penelitian tindakan kelas (PTK). Penelitian ini bertujuan untuk meningkatkan hasil belajar siswa pada pembelajaran IPS melalui penerapan model project based learning. Penelitian tindakan kelas ini dilaksanakan dalam dua siklus yang terdiri atas empat tahapan pelaksanaan, yakni perencanaan, tindakan, observasi, dan refleksi. Teknik pengumpulan data dilakukan melalui tes tertulis pada setiap akhir siklus dengan menggunkan instrumen soal pilihan ganda. Hasil penelitian menunjukkan terdapat peningkatan hasil belajar siswa pada pembelajaran IPS dari siklus I ke siklus II dengan presentase peningkatan hasil belajar siswa $85 \%$ dari 20 siswa telah mencapai nilai standar ketuntasan minimum. Peningkatan hasil belajar siswa tersebut terjadi karena meningkatnya keterampilan siswa memecahkan masalah ketika model project based learning diterapkan pada pelaksanaan kegiatan pembelajaran.

Kata Kunci: Hasil Belajar, Pembelajaran IPS, Project Based Learning
INDONESIAN JOURNAL OF EDUCATIONAL STUDIES (IJES)

\section{E-ISSN: 2621-6744 \\ P-ISSN: 2621-6736}

Submitted: June $21^{\text {st }} 2018$

Accepted: July $13^{\text {th }} 2018$

Abstract. This research is a descriptive qualitative study that uses a class action research design. This study aims to improve student learning outcomes in social studies learning through the application of project based learning models. Classroom action research is carried out in two cycles consisting of four stages of implementation, namely planning, action, observation, and reflection. Data collection techniques were carried out through written tests at the end of each cycle by using multiple choice instruments. The results showed there was an increase in student learning outcomes in social studies learning from cycle I to cycle II with a percentage increase in student learning outcomes $85 \%$ of the 20 students had reached the minimum standard of completeness. The increase in student learning outcomes occurs because of increasing students' skills in solving problems when the project based learning model is applied to the implementation of learning activities. 


\section{PENDAHULUAN}

Seiring perkembangan teknologi informasi yang semakin maju menuntut bekal pendidikan yang memadai bagi setiap anggota masyarakat. Pendidikan merupakan kebutuhan penting bagi pembangunan bangsa yang berkualitas. Penyiapan sumber daya manusia berkualitas suatu bangsa dapat dilakukan melalui pendidikan yang terencana dan berkesinambungan. Dalam UU Sisdiknas No. 20 tahun 2003 pasal 3 dijelaskan bahwa tujuan pendidikan nasional berfungsi mengembangkan kemampuan membentuk watak dan membentuk peradaban bangsa yang bermartabat dalam rangka mencerdaskan kehidupan bangsa, bertujuan untuk berkembangnya potensi peserta didik agar menjadi manusia yang beriman dan bertagwa terhadap Tuhan Yang Maha Esa, dan menjadi warga negara yang demokratis serta bertanggung jawab.

Mata pelajaran IImu Pengetahuan Sosial (IPS) merupakan mata pelajaran yang penting untuk dikembangkan karena memberikan edukasi kepada siswa untuk menjadi warga masyarakat yang baik. Hal ini sesuai dengan salah satu substansi tujuan mata pelajaran IPS yang telah ditetapkan, yaitu memiliki kemampuan dasar untuk berpikir logis dan kritis, rasa ingin tahu, inkuiri, memecahkan masalah, dan keterampilan dalam kehidupan sosial. (Depdiknas dalam Supardan, 2015) Tujuan mata pelajaran IPS menurut Chapin dan Messick (dalam Al-lamri dan Istianti (2006) diantaranya adalah, 1) membina pengetahuan siswa tentang pengalaman manusia dalam kehidupan bermasyarakat pada masa lalu, sekarang, dan dimasa yang akan datang, 2) menolong siswa untuk mengembangkan keterampilan (skill) untuk mencari dan mengolah atau memproses informasi, dan 3) menolong siswa untuk mengembangkan nilai atau sikap (value) demokrasi dalam kehidupan bermasyarakat.

Memperhatikan tujuan mata pelajaran IPS tersebut, pada kenyataannya hasil belajar siswa pada pembelajaran IPS di sekolah khususnya di kelas V SD Inpres No. No 26 Barang Kecamatan Barru, Kabupaten Barru belum menunjukkan hasil belajar yang seperti apa yang menjadi tujuan mata pelajaran IPS. Hasil belajar merupakan bagian terpenting dalam pembelajaran. Sudjana (2009) mendefinisikan hasil belajar siswa pada hakikatnya adalah perubahan tingkah laku sebagai hasil belajar dalam pengertian yang lebih luas mencakup bidang kognitif, afektif, dan psikomotorik. Selanjutnya, Dimyati dan Mudjiono (2006) juga menyebutkan hasil belajar merupakan hasil dari suatu interaksi tindak belajar dan tindak mengajar. Bloom mengemukakan secara garis besar membagi hasil belajar menjadi tiga ranah, yaitu ranah kognitif, ranah afektif dan ranah psikomotorik (Sudjana, 2009).

Hasil studi awal yang dilakukan di SD Inpres No. 26 Barang Kecamatan Barru, Kabupaten Barru pada hari Senin - Rabu, tanggal 4 - 6 Januari 2018 ditemukan bahwa hanya 35\% dari 20 siswa (hanya 7 orang) yang memenuhi standar Kriteria Ketuntasan Minimal (KKM) yaitu nilai 75 pada hasil belajar siswa pada pembelajaran IPS. Rendahnya hasil belajar siswa di kelas ini disebabkan oleh faktor guru dan faktor siswa pada pelaksanaan pembelajaran. Faktor guru yaitu: 1) pembelajaran yang dilakukan dalam kelas kurang kreatif, 2) pembelajaran yang dilakukan masih menggunakan metode konvensional sehinga kurang efektif untuk mengembangkan daya serap siswa; dan 3) kurang mengembangkan keterampilan siswa melalui 
pemberian tugas kreatif yang dapat membangun kerja sama kelompok dalam pembelajaran.

Adapun faktor siswa yaitu; 1) pengetahuan siswa tentang materi pelajaran yang diberikan masih rendah dilihat berdasarkan hasil semester ganjil yang menunjukkan sebagian besar siswa belum memenuhi kriteria ketuntasan minimal, 2) siswa kurang kreatif memanfaatkan bahan ajar yang tersedia karena keterampilannya kurang dikembangkan dalam pembelajaran, dan 3) siswa kurang kompak dalam kerjasama kelompok ketika menyelesaikan tugas yang diberikan guru. Untuk mengatasi permasalahan tersebut, perlu memilih model pembelajaran yang dapat meningkatkan hasil belajar siswa pada pembelajaran IPS. Salah satu model pembelajaran yang efektif untuk mengatasi masalah tersebut adalah model Project Based Learning.

Project Based Learning merupakan model pembelajaran yang memberikan kesempatan kepada guru untuk mengelola pembelajaran di kelas dengan melibatkan kerja proyek (Thomas dalam Wena, 2014). Kerja proyek ini melibatkan siswa dalam setiap tahap prosesnya sehingga fokus, respon, kreatifitas, dan daya serap siswa terhadap pembelajaran IPS bisa dimaksimalkan. Pendapat serupa juga dinyatakan oleh Santyasa (Supardan, 2015), yang menyatakan bahwa Project Based Learning adalah suatu pembelajaran yang berfokus pada konsep dan memfasilitasi siswa untuk berinvestigasi dan menentukan suatu pemecahan masalah yang dihadapi.

Project Based Learning diketahui sangat mendukung pelaksanaan kurikulum 2013 untuk mencapai tujuan pembelajaran IPS. Mengingat Project Based Learning merupakan pembelajaran yang komprehensif mengikutsertakan siswa untuk melakukan investigasi secara kolaboratif yang menuntut solidaritas dalam melakukan tugas-tugas kompleks (Supardan, 2015: 137). Model pembelajaran ini sangat cocok dipadukan dengan materi IPS. Berdasarkan kegiatan pembelajaran dalam silabus, materi IPS menuntut siswa untuk aktif (student centered) sedangkan guru bertindak sebagai fasilitator dan motivator, siswa bekerja sama dengan berbagai percobaan seperti percobaan pengelompokan berbagai sistem pembelajaran IPS,

Penerapan model Project Based Learning potensial memenuhi tuntutan pembelajaran. Hal ini didasarkan pada suksesnya penerapan Project Based Learning dalam beberapa penelitian terdahulu, diantara dilakukan oleh Suhartadi (dalam Wena, 2014) menyimpulkan bahwa model pembelajaran berbasis proyek terbukti dan teruji sebagai model belajar atau pembelajaran yang mampu menumbuhkan kemandirian siswa, khususnya pada pembelajaran yang memungkinkan untuk dilaksanakan kerja proyek.

Langkah-langkah pelakasanaan kegiatan pembelajaran model Project Based Learning dapat memberdayakan kemampuan berfikir kritis dan sikap siswa terhadap lingkungan. Hal ini mengacu pada sintaks yang dikembangkan Mahanal (dalam Supardan, 2015) sangat mendukung pemberdayaan berfikir kritis. Adapun sintaks Project Based Learning yang dimaksud sebagai berikut: 1) planning; 2) creating; 3) processing. 
Planning, dalam implementasinya mencangkup persiapan proyek dan perencanaan proyek yang sistematis. Pada tahap ini menghadapkan siswa pada masalah riil di lapangan, dan mendorong mereka untuk mengidentifikasi masalah tersebut yang selanjutnya siswa diminta menentukan alternatif pemecahan masalah serta mendesain model memecahkan masalah yang aspiratif berdasarkan kemampuan dan kebutuhan mereka. Creating, yaitu pelaksanaan proyek yang memberikan kesempatan seluas-luasnya pada siswa untuk berekspresi dalam merancang dan melakukan investigasi serta mempresentasikan laporan (produk) baik secara lisan maupun tulisan. Processing, yakni meliputi presentasi proyek dan evaluasi proyek. Presentasi proyek yaitu mengkomunikasikan secara aktual kreasi atau temuan dari investigasi kelompok termasuk refleksi dan tindak lanjut proyekproyek. Evaluasi yang dilakukan pada tahap ini mencangkup evaluasi teman sebaya, evaluasi diri, dan portofolio.

Secara umum sintaks Project Based Learning memperlihatkan bahwa dalam pembelajaran berbasis proyek siswa dapat belajar secara aktif untuk merumuskan masalah, melakukan penyelidikan, menganalisis dan menginterpretasikan data, serta mengambil keputusan untuk memecahkan masalah yang dihadapainya. Uraian diatas mengindikasikan bahwa dengan diterapkanya model Project Based Learning pada pembelajaran IPS dapat meningkatkan hasil belajar siswa pada pembelajaran IPS. Olehnya itu penulis terdorong untuk melakukan penelitian tindakan kelas pada siswa kelas V di SD Inpres No 26 Barang, Kabupaten Barru.

\section{METODE PENELITIAN}

Pendekatan yang digunakan dalam penelitian ini adalah pendekatan kualitatif deskriptif. Sugiyono (2014) mengemukakan bahwa "metode penelitian kualitatif sering disebut metode penelitian naturalistik kerena penelitiannya dilakukan pada kondisi yang alamiah (natural setting)". Penelitian ini menggunakan rancangan Penelitian Tindakan Kelas (PTK) selama dua siklus yang didasarkan atas dua pertimbangan alokasi waktu dan topik yang dipilih masing-masing siklus terdiri atas empat langkah yaitu perencanaan, pelaksanaan, observasi, dan refleksi.

Penelitian tindakan kelas ini dilaksanakan dalam bentuk dua siklus yang terdiri atas empat tahapan pelaksanaan, yakni perencanaan, tindakan, observasi, dan refleksi yang dilakukan dalam dua siklus secara berkesinambungan berdasarkan kriteria penelitian tindakan kelas yang dirumuskan. Fokus penelitian tindakan kelas ini adalah model Project Based Learning dan hasil belajar siswa. Subjek dalam penelitian ini adalah satu orang guru dan siwa kelas V SD Inpres No. 26 Barang Kabupaten Barru dengan jumlah 20 siswa yang terdiri dari 9 orang laki - laki dan 11 orang perempuan yang aktif dan terdaftar pada semester genap 2015/2016.

Adapun Teknik pengumpulan data dilakukan melalui tes tertulis pada setiap akhir siklus dengan menggunkan instrumen soal pilihan ganda. Tes tertulis dilakukan untuk mendapatkan data tentang hasil belajar siswa pada pembelajaran IPS. Analisis data dilakukan berdasarkan model mengalir yang ditawarkan oleh Miles dan Huberman (dalam Sugiyono, 2014), yakni analisis data yang dimulai dengan menelaah data sejak pengumpulan data sampai dengan seluruh data terkumpul. Hal ini dilakukan untuk menghindari penumpukan data dan peneliti dapat dengan segera memberikan refleksi terhadap data sehingga proses pemahaman dan 
simpulannya yang diambil bisa lebih tepat. Selanjutnya dilakukan pengkategorian presentase aktivitas belajar siswa dalam skala deskriptif yang diadopsi dalam Arikunto (Lolotandung, 2014) sebagai berikut:

Tabel 1. Kategorisasi Aktivitas Belajar Siswa

\begin{aligned} & \hline \multicolumn{1}{c}{ Skor } \multicolumn{1}{c}{ Kategori } \\ & \hline $68 \%-100 \%$ Baik \\ & $34 \%-67 \%$ Cukup \\ & $0 \%-33 \%$ Kurang \\ & \hline\end{aligned}

Indikator keberhasilan pada pelaksanaan penelitian ini adalah hasil belajar siswa. kriteria yang digunakan untuk mengambarkan peningkatkan hasil pemahaman siswa dalam pembelajaran IPS adalah sesuai dengan kriteria standar yang ditetapkan Depertemen Pendidikan Nasional (dalam Lolotandung, 2014), yaitu: "tingkat penguasaan 85\% - 100\% dikategorikan sangat tinggi, 65\% - 84\% dikategorikan tinggi, 55\% - 64\% dikategorikan cukup, 35\% - 54\% dikategorikan rendah dan 0\% - 34\% dikategorikan sangat rendah.

Tabel 2.

Teknik Kategorisasi Standar Berdasarkan Ketetapan Depdiknas (dalam Lolotandung, 2014)

\begin{tabular}{ll}
\hline Skor & Kategori \\
\hline $0-34$ & Sangat Rendah \\
$35-54$ & Rendah \\
$55-64$ & Cukup \\
$65-84$ & Tinggi \\
$85-100$ & Sangat Tinggi \\
\hline
\end{tabular}

Berdasarkan taraf indikator keberhasilan di atas, maka peneliti memilih dan menetapkan standar minimal keberhasilan dalam penelitian ini dari segi hasil adalah bila $85 \%$ dari jumlah siswa mendapatkan nilai hasil belajar $\geq 75$. Penelitian ini telah dilaksanakan berdasarkan prosedur PTK yang terdiri dari empat tahap, yaitu tahap perencanaan, pelaksanaan, observasi dan refleksi. Pelaksanaan tindakan berlangsung selama dua siklus pada semester genap tahun ajaran 2015-2016 di Kelas V SD Inpres No. 26 Barang Kecamatan Barru Kabupaten Barru. Pelaksanaan penelitian dimulai pada tanggal 11 April 2016 sampai tanggal 2 Mei 2016. Dalam pelaksanaan tindakan, peneliti bertindak sebagai guru dan guru kelas $\mathrm{V}$ bertindak sebagai observer.

\section{HASIL DAN PEMBAHASAN}

Hasil penelitian yang diperoleh berupa berupa data hasil belajar siswa pada pembelajaran IPS. Data hasil belajar siswa diperoleh melalui tes pada akhir siklus I dan siklus II Hasil belajar siswa pada siklus I diperoleh data sebagai berikut; ada 8 dari 20 siswa kelas V SD Inpres No. 26 Barang Kabupaten Barru yang memenuhi nilai Kriteria Ketuntasan Minimal (KKM) yaitu 75 sehingga ketuntasan klasikal yang 
dicapai pada siklus I yaitu 40\%. Hal ini berarti masih ada 12 orang siswa yang belum mencapai nilai KKM dengan persentase ketidaktuntasan yaitu 60\%. Oleh karena itu penelitian dilanjutkan pada siklus II.

Tabel 3. Distribusi Frekuensi dan Persentase Nilai Hasil Belajar Siswa Siklus I

\begin{tabular}{cccc}
\hline Skor & Predikat & Frekuensi & Persentase \\
\hline $0-34$ & Sangat Rendah & 4 & $20 \%$ \\
$35-54$ & Rendah & 7 & $35 \%$ \\
$55-64$ & Cukup & 1 & $5 \%$ \\
$65-84$ & Tinggi & 5 & $25 \%$ \\
$85-100$ & Sangat Tinggi & 3 & $15 \%$ \\
& Jumlah & 20 & 100 \\
\hline
\end{tabular}

Hasil belajar siswa siklus II pada pembelajaran IPS di kelas V SD Inpres No. 26 Barang Kabupaten Barru diperoleh ada 17 dari 20 orang siswa yang memenuhi nilai KKM yaitu 75 dengan persentase $85 \%$. Hasil tes tersebut menunjukkan ada 3 orang siswa yang belum mencapai nilai KKM dengan persentase $15 \%$.

Tabel 4. Distribusi Frekuensi dan Persentase Nilai Hasil Belajar Siswa Siklus II

\begin{tabular}{|c|c|c|c|}
\hline Skor & Predikat & Frekuensi & Persentase \\
\hline $0-34$ & Sangat Rendah & 1 & $5 \%$ \\
\hline $35-54$ & Rendah & 0 & $0 \%$ \\
\hline $55-64$ & Cukup & 0 & $0 \%$ \\
\hline $65-84$ & Tinggi & 6 & $30 \%$ \\
\hline \multirow[t]{2}{*}{$85-100$} & Sangat Tinggi & 13 & $65 \%$ \\
\hline & Jumlah & 20 & 100 \\
\hline
\end{tabular}

Hasil belajar siswa pada siklus II menunjukkan capaian sangat tinggi dengan persentasi ketuntasan $85 \%$. Sehingga dapat disimpulkan pelaksanaan tindakan siklus II telah meningkat dan memenuhi standar ketuntusan minimal. Peningkatan hasil belajar siswa pada pembelajaran IPS dari siklus I ke siklus II sejalan dengan pendapat Wena (2014: 32) mengemukakan bahwa pembelajaran berbasis proyek bersandar pada ide bahwa siswa membangun pengetahuannya sendiri didalam konteks pengalamannya sendiri.

Pembelajaran berbasis proyek dapat dipandang sebagai salah satu pendekatan penciptaan lingkungan belajar yang dapat mendorong siswa mengkonstruk pengetahuan dan keterampilan secara personal. Ketika pembelajaran berbasis proyek dilakukan dalam model belajar kolaboratif dalam kelompok kecil siswa. Adanya peluang untuk menyampaikan ide, mendengarkan ide orang lain, dan merefleksikan ide sendiri pada orang lain, adalah suatu bentuk pembelajaran individu. Proses interaktif dengan kawan sejawat membantu proses konstruksi pengetahuan. Dari perspektif teori ini pembelajaran berbasis proyek 
dapat membantu siswa meningkatkan keterampilan dan memecahkan masalah secara kolaboratif.

\section{KESIMPULAN}

Berdasarkan hasil penelitian dan pembahasan dapat disimpulkan bahwa penerapan model Project Based Learning dapat meningkatkan hasil belajar siswa pada pembelajaran IPS kelas V SD Inpres No. 26 Barang Kabupaten Barru. Hasil penelitian menunjukkan hasil belajar siswa pada pembelajara IPS pada tiap siklus mengalami peningkatan. Hal ini dapat dilihat pada data hasil belajar siswa pada siklus I berada pada kategori rendah meningkat pada siklus II pada kategori tinggi. Kesimpulan pada penelitian ini adalah terjadi peningkatan hasil belajar siswa pada pembelajaran IPS melalui penerapan model Project Based Learning di kelas V SD Inpres No. 26 Barang Kabupaten Barru.

\section{DAFTAR PUSTAKA}

Al-Lamri, I. H dan Ichas, T. I. (2006). Pengembangan Pendidikan Nilai dalam Pelajaran Pengetahuan Sosial di SD. Jakarta: Depdiknas.

Arikunto, S. (2007). Dasar-Dasar Evaluasi Pendidikan. Penerbit Bumi Aksara, Jakarta Dimyati dan Mudjiono. (2006). Belajar dan Pembelajarn. Jakarta: Penerbit Rineka Cipta.

Lolotandung, Reni. (2014). Penerapan Model Pembelajaran Kooperatif Tipe Make A Match dalam Meningkatkan Hasil Belajar Matematika pada Siswa Kelas IV SD Inpres Gunungsari Baru Makassar. Skripsi. Makassar: PGSD FIP UNM

Sudjana, Nana. (2009). Penilain Hasil Proses Belajar Mengajar. Bandung: Remaj Rosdakarya.

Sugiono. (2014). Metode Penelitian Kuantitatif dan Kualitatif dan R \& D. Bandung: Alfabeta

Supardan, Dadang. (2015). Pembelajaran Ilmu Pengetahuan Sosial: Perspektif Filosofi dan Kurikulum. Jakarta: Bumi Aksara.

Undang-Undang Sisdiknas No. 20 Tahun 2003. Jakarta: Sinar Grafika

Wena, Made. (2014). Strategi Pembelajaran Inovatif Kontemporer. Jakarta: Bumi Aksara. 